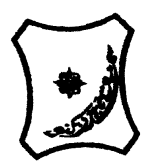

Bayero Journal of Pure and Applied Sciences, 14(1):142 - 151

Received: April, 2021

Accepted: June, 2021

ISSN $2006-6996$

\title{
EFFECTS OF SALICYLIC AND BENZOIC ACID ON YIELD AND YIELD COMPONENTS OF MOISTURE STRESSED TOMATO (SOlanum Iycopersicun L.) AT KADAWA SUDAN SAVANNAH
}

\author{
Isa, H. M. and Manga, A.A. \\ Department of Agronomy, Faculty of Agriculture, Bayero University, P. M. B. 3011, Kano, Nigeria. \\ *corresponding author email: hmisa.agr@buk.edu.ng
}

\begin{abstract}
Salicylic acid and Benzoic acids are antitranpirants usually used to reduce the rate of moisture loss and increase productivity of irrigated crops. To test antitranspiracy of Salicylic and Benzoic acids, field experiments were conducted during the two successive dry Seasons of 2011/2012 and 2012/2013 at the Agricultural Research Station Farm, Kadawa (11 38'40.3" $\left.N, 8^{\circ} 25^{\prime} 53.9^{\prime \prime} \mathrm{E}\right) 498 \mathrm{~m}$ elevation above sea level. The aim was to study the effects of antitranspirants and moisture stress on crop growth and development stages of tomato. The treatments consisted of two antitranspirants at four different concentrations of 0,200, 400 and 600 ppm, and three moisture stress stages, vegetative, flowering and fruit setting. Antitranspirants and moisture stresses were assigned to the main plot and concentrations were used as sub-plot treatment. These were replicated three times and laid out in a split-plot design. The gross plot size was $3.6 \mathrm{~m} \times 3.0 \mathrm{~m}\left(10.8 \mathrm{~m}^{2}\right)$ consisting of 6 rows of $3 \mathrm{~m}$ length, while the net plot size was $1.2 \mathrm{~m}$ $x 1.8 m\left(2.16 \mathrm{~m}^{2}\right)$ consisting of 2 inner most rows. Data were taken on tomato growth and yield attributes. Data generated were analysed using statistical analytics software (SAS). The results of the study revealed that application of both Antitranspirants enhanced growth and yield components such as fruit diameter, number of fruits plant ${ }^{1}$, average fruit weight, marketable fruit yield and total fruit yield of tomato. Significant interactions between and among the factors were also recorded for fruit diameter, number of fruits plant $^{-1}$, marketable fruit yield and the total fruit yield. Application of 200 and 400 ppm of antitranspirant had higher fruit weight, number of marketable fruits and higher total fruit yield. Imposing stress at vegetative stage had higher total fruit yield than other stages. Similarly, 600 ppm of Benzoic acid at flowering had higher number of marketable fruits (16.37 $t \mathrm{ha}^{-1}$ ) while the control (3.18 $\mathrm{ha}^{-1}$ ) had the least in 2012. Applying $400 \mathrm{ppm}$ of Salicylic acid at fruit setting produced the highest total fruit yield $\left(6.66\right.$ tha $\left.^{-1}\right)$ which was statistically similar to $600 \mathrm{ppm}$ of Benzoic $\left(6.10 \mathrm{t} \mathrm{ha}^{-1}\right)$ at flowering while the control had the lowest. Total fruit yield was positively and significantly correlated with number of fruit plant ${ }^{1}$ and average fruit weight. Number of fruits plant ${ }^{1}$ was found to have the highest direct contribution to the yield. Flowering and fruiting stages were found to be the critical growth stages for moisture stress of tomato. Foliar application of 400 ppm of Salicylic acid at fruit setting stage appeared to promote tomato yield in the study area.
\end{abstract} Key words: Salicylic acid, Benzoic acid, Yield components, Tomato, Moisture stress

\section{INTRODUCTION}

Tomato (Solanumlycopersicum L.) belongs to the family Solanaceae. The Spaniard introduced tomato into Europe in the early $16^{\text {th }}$ Century (Harvey et al., 2002) and subsequently to Africa through Gibraltar and Morocco. Tomatoes were initially grown only as ornamental plants; fruits were considered to be poisonous because of the closely related and deadly night shade (Solanumdulcamara). Eaten raw or in cooked dishes, today the tomato is an almost daily part of the American diet. Cultivation of tomato is now widespread throughout the temperate and tropical climate (Harlan, 1984).It is currently the most important commercial vegetable grown in Nigeria. The cultivated tomato reached its present status after a long period of domestication and it is now grown throughout the temperate and tropical climates (Harvey et al., 2002). The area of major production is the Northern part of the country, between latitude $8^{0}-13^{0} \mathrm{~N}$, but the greatest market is mostly in the South and other neighboring countries (Amans et al., 1986). 
BAJOPAS Volume 14 Number 1,June, 2021

Tomatoes are one of the most widely eaten vegetables in the world. Their popularity stems from the fact that it can be eaten fresh or in multiple of processed forms. It is a versatile health product and due to its equally versatile preparation option, there is really no reason to neglect the tomato as part of a healthy diet. Cancers such as prostate cancers, cervical cancer, colon cancer, rectal cancer and the cancer of the stomach and mouth have all been proven to be reduced off by high levels of lycopene (Inmaculada et al., 2011). Tomatoes require a high water potential for optimal vegetative and reproductive development. Rains vary from year to year and its distribution is not uniform throughout the growing season. However, optimizing water use is an economic and environmental concern for agricultural producers. Therefore, fresh market growers are interested in developing management strategies that could help reduce total amount of irrigation water without affecting crop yield and fruit quality. In arid and semi- arid regions, water is the main limiting factor for plant growth. Moreover, plants are prodigal (wasteful) in their water use because only roughly $5 \%$ of water uptake is used for its growth and development while the remaining $95 \%$ is lost in transpiration. One way to achieve this goal is by reducing the transpiration rate using Antitranspirant materials to minimize the amount of irrigation water. Film forming antitranspirants when sprayed on to plants supposedly form a continuous layer over the leaf surfaces which are permeable to gases for example carbon dioxide and oxygen but impermeable to water vapour. The reduced transpiration enhances plant survival especially under hot climatic conditions with reduced soil water potential. Not much work has been done on the use of antitranspirants to reduce water lost into the atmosphere in Nigeria. It is against this background that the experiment was conceived with the following objectives: to determine the effects of antitranspirants, their concentrations and moisture stress on the growth, yield and yield components of tomato.

\section{MATERIALS AND METHODS}

The experiment was conducted for the two successive dry seasons of 2011/2012 and 2012/2013 at the Agricultural Research Station Farm, Kadawa ( $\left.11^{\circ} 38^{\prime} 40.3^{\prime \prime} \mathrm{N}, 8^{\circ} 25^{\prime} 53.9^{\prime \prime} \mathrm{E}\right)$ $498 \mathrm{~m}$ elevation above sea level. The treatments consisted of two antitranspirants (Benzoic and Salicylic acids) at four concentrations each (0, 200, 400 and $600 \mathrm{ppm}$ ) and three moisture stress stages (vegetative, flowering and fruit setting). These were arranged in a split-plot design and replicated three times. The gross plot size was $3.6 \mathrm{~m} \times 3.0 \mathrm{~m}\left(10.8 \mathrm{~m}^{2}\right)$ consisting of 6 rows of $3 \mathrm{~m}$ length, while the net plot size was $1.2 \mathrm{~m} \times 1.8 \mathrm{~m}\left(2.16 \mathrm{~m}^{2}\right)$ consisting of 2 inner most rows. The experimental site was ploughed, harrowed and prepared into plots of slightly sunken beds of $3.6 \mathrm{~m} \times 3.0 \mathrm{~m}\left(10.8 \mathrm{~m}^{2}\right)$ sizes. Paired rows of beds were separated by $0.75 \mathrm{~m}$ wide irrigation channels between the plots. Seedlings were transplanted at a spacing of 60 $\mathrm{cm} \times 60 \mathrm{~cm}$. Salicylic and Benzoic acids were sprayed to the foliage using a hand sprayer at vegetative, flowering and fruit setting stages at the rate of $0,200,400$ and $600 \mathrm{ppm}$ equivalent to $0.2,0.4$ and $0.6 \mathrm{~g} \mathrm{~L}^{-1}$ of water. All plots received full rates of $P$ and $K\left(20\right.$ and $37 \mathrm{Kg} \mathrm{ha}^{-1}$ respectively) in form of SSP and MOP after land preparation. The first rate of $\mathrm{N}\left(45 \mathrm{Kg} \mathrm{N} \mathrm{ha}^{-1}\right)$, in form of urea was applied one week after transplanting. The remaining balance of $45 \mathrm{Kg} \mathrm{N}$ $\mathrm{ha}^{-1}$ was applied in form of urea in two split applications at three and six weeks after transplanting through banding method of application. Agronomic practices required for successful production of tomato were carried out. Data were collected on fruit diameter, number of fruits plant ${ }^{-1}$, average fruit weight, marketable fruit yield and total fruit yield (Materials and methods).

\section{RESULTS}

Results of moisture stress and antitranspirants on fruit diameter of tomato are presented in Table 1. There was no significant difference between the antitranspirants and the stress stages on fruit diameter in both seasons and combined. However, concentration of antitranspirant had significant effect on fruit diameter in both seasons and combined. Application of $400 \mathrm{ppm}$ recorded the highest fruit diameter of $92.81 \mathrm{~mm}$, while the control had the lowest diameter of $71.95 \mathrm{~mm}$ in 2012 season. In 2013 season, application of 200ppm of Antitranspirant recorded the highest $(99.45 \mathrm{~mm})$ fruit diameter while the control had the lowest $(77.31 \mathrm{~mm})$. Similar trend was observed in 2012 and 2013 seasons as well as combined. There was significant interaction between antitranspirant and stress on fruit diameter of tomato (Table 1 ).

The effect of antitranspirants and moisture stress on number of fruits plant ${ }^{-1}$ of Tomato is presented in Table 2. There was no significant difference between the two antitranspirants in both seasons and combined. 
BAJOPAS Volume 14 Number 1,June, 2021

Stress had significant effect on number of fruits plant $^{-1}$ of Tomato only in 2013 season. In 2013 season, imposing stress at flowering stage had plants with significantly lowest number of fruits plant $^{-1}$ when compared to fruiting stage and was at par with vegetative stage. Concentration also had significant effect on number of fruits plant ${ }^{1}$ of Tomato in bothseasons and combined. Application of 400ppm of the Antitranspirant and $0 \mathrm{ppm}$ recorded plants withthe highest (11.11) and lowest (7.06) number of fruits plant ${ }^{-1}$ in 2012 season. Similar trend was observed in 2013 season and combined. There was significant interaction between antitranspirants and concentration on number of fruits plant ${ }^{-1}$ of Tomato in 2012 season and significant interaction between stress and concentration on number of fruits plant ${ }^{-1}$ of Tomato in 2013 season (Table 2).
Table 3 shows the effect of antitranspirant and moisture stress on average fruit weight of tomato.

There was significant difference between the antitranspirants on fruit weight of tomato in 2012 season and combined. In 2012 season and combined, application of Salicylic acid recorded plants with heavier fruit weights $(66.84 \mathrm{~g}$ and $58.04 \mathrm{~g}$ ) while application of Benzoic acid had plants with lighter fruit weights $(56.66 \mathrm{~g}$ and $51.87 \mathrm{~g})$.Stress had no significant effect on average fruit weight plant $^{-1}$ of tomato in both seasons and combined. Concentration of antitranspirant had significant effect on average fruit weight plant ${ }^{-1}$ of tomato only in 2012 season where application of $200 \mathrm{ppm}$ of antitranspirant had plants with the highest average fruit weight plant $^{-1}(70.32 \mathrm{~g})$ while the control had the lowest weight (56.66g) (Table 3).

Table 1: Effect of Antitranspirants and Moisture Stress on Fruit Diameter (mm) of Tomato at Kadawa in 2012, 2013 Dry Seasons and Combined.

\begin{tabular}{|c|c|c|c|}
\hline \multirow[t]{2}{*}{ Treatments } & \multicolumn{3}{|c|}{ KADAWA } \\
\hline & 2012 & 2013 & Combined \\
\hline \multicolumn{4}{|l|}{ Antitranspirants (A) } \\
\hline Benzoic acid & 80.32 & 86.02 & 83.17 \\
\hline Salicylic acid & 87.14 & 86.48 & 86.81 \\
\hline Level of significance & NS & NS & NS \\
\hline $\mathrm{SE} \pm$ & 7.130 & 5.400 & 4.590 \\
\hline \multicolumn{4}{|l|}{ Stress (S) } \\
\hline Vegetative & 92.39 & 88.49 & 90.44 \\
\hline Flowering & 86.14 & 85.08 & 85.61 \\
\hline Fruit setting & 72.66 & 85.17 & 78.91 \\
\hline Level of significance & NS & NS & NS \\
\hline $\mathrm{SE} \pm$ & 7.130 & 5.400 & 4.590 \\
\hline \multicolumn{4}{|c|}{ Concentrations ppm (C) } \\
\hline 0 & $71.95 b$ & $77.31 \mathrm{~b}$ & $74.63 \mathrm{~b}$ \\
\hline 200 & $83.87 a$ & $99.45 a$ & $91.66 a$ \\
\hline 400 & $92.81 a$ & $83.05 b$ & $87.93 a$ \\
\hline 600 & $86.03 a$ & $85.18 \mathrm{~b}$ & $85.74 a$ \\
\hline Level of significance & $*$ & $*$ & $*$ \\
\hline $\begin{array}{l}\text { SE } \pm \\
\text { Interactions (I) }\end{array}$ & 5.410 & 3.420 & 3.750 \\
\hline$A \times S$ & $*$ & NS & NS \\
\hline$A \times C$ & NS & NS & NS \\
\hline $\mathrm{S} \times \mathrm{C}$ & NS & NS & NS \\
\hline$A \times S \times C$ & NS & NS & NS \\
\hline
\end{tabular}


BAJOPAS Volume 14 Number 1,June, 2021

Table 2: Effect of Antitranspirant and Moisture Stress on Number of Fruits Plant ${ }^{-1}$ of Tomato at Kadawa in 2012, 2013 Dry Seasons and Combined.

\begin{tabular}{|c|c|c|c|}
\hline \multirow[t]{2}{*}{ Treatments } & \multicolumn{2}{|c|}{ KADAWA } & \multirow[b]{2}{*}{ Combined } \\
\hline & 2012 & 2013 & \\
\hline \multicolumn{4}{|l|}{ Antitranspirants (A) } \\
\hline Benzoic acid & 8.26 & 9.08 & 8.67 \\
\hline Salicylic acid & 10.78 & 7.66 & 9.22 \\
\hline Level of significance & NS & NS & NS \\
\hline $\mathrm{SE}+$ & 2.091 & 0.574 & 0.711 \\
\hline \multicolumn{4}{|l|}{ Stress (S) } \\
\hline Vegetative & 9.46 & $8.50 a b$ & 8.98 \\
\hline Flowering & 10.04 & $7.42 b$ & 8.73 \\
\hline Fruit setting & 9.04 & $9.20 \mathrm{a}$ & 9.12 \\
\hline Level of significance & NS & $*$ & NS \\
\hline $\mathrm{SE} \pm$ & 2.091 & 0.574 & 0.711 \\
\hline \multicolumn{4}{|c|}{ Concentrations ppm (C) } \\
\hline 0 & $7.06 c$ & $6.86 \mathrm{~b}$ & $6.96 c$ \\
\hline 200 & $11.00 a$ & $8.26 \mathrm{~b}$ & 9.63ab \\
\hline 400 & $11.11 \mathrm{a}$ & $10.03 a$ & $10.57 a$ \\
\hline 600 & $8.90 \mathrm{~b}$ & $8.35 b$ & $8.62 b$ \\
\hline Level of significance & $* *$ & $*$ & $* *$ \\
\hline $\begin{array}{l}\text { SE } \pm \\
\text { Interactions (I) }\end{array}$ & 0.873 & 0.481 & 0.580 \\
\hline$A \times S$ & NS & NS & NS \\
\hline$A \times C$ & $*$ & NS & NS \\
\hline$S \times C$ & NS & $*$ & NS \\
\hline$A \times S \times C$ & NS & NS & NS \\
\hline
\end{tabular}

Means followed by the same letter (s) in a column are not significantly different at $5 \%$ level of probability using Student-Newman Keuls Test. ${ }^{*}=$ significant at $5 \% ; * *=$ significant at $1 \%$; NS $=$ not significant

Table 3: Effect of Antitranspirants and Moisture Stress on Average Fruit Weight (g) Plant ${ }^{-1}$ of Tomato at Kadawa in 2012, 2013 Dry Seasons and Combined.

\begin{tabular}{|c|c|c|c|}
\hline \multirow[t]{2}{*}{ Treatments } & \multicolumn{3}{|c|}{ KADAWA } \\
\hline & 2012 & 2013 & Combined \\
\hline \multicolumn{4}{|l|}{ Antitranspirants (A) } \\
\hline Benzoic acid & $56.66 \mathrm{~b}$ & 47.07 & 51.87 \\
\hline Salicylic acid & $66.84 a$ & 49.24 & 58.04 \\
\hline Level of significance & $*$ & NS & NS \\
\hline $\begin{array}{l}\text { SE } \pm \\
\text { Stress (S) }\end{array}$ & 2.610 & 2.840 & 3.240 \\
\hline Vegetative & 61.73 & 49.23 & 55.48 \\
\hline Flowering & 62.67 & 47.73 & 55.20 \\
\hline Fruit setting & 60.85 & 47.50 & 54.18 \\
\hline Level of significance & NS & NS & NS \\
\hline $\begin{array}{l}\mathrm{SE} \pm \\
\text { Concentrations ppm (C) }\end{array}$ & 2.610 & 2.840 & 3.240 \\
\hline 0 & $56.66 \mathrm{~b}$ & 45.44 & 51.05 \\
\hline 200 & $70.32 a$ & 46.64 & 58.48 \\
\hline 400 & $60.23 b$ & 51.05 & 55.64 \\
\hline 600 & $59.80 \mathrm{~b}$ & 49.49 & 54.65 \\
\hline Level of significance & $*$ & NS & NS \\
\hline $\begin{array}{l}\mathrm{SE} \pm \\
\text { Interactions (I) }\end{array}$ & 2.380 & 2.140 & 2.650 \\
\hline$A \times S$ & NS & NS & NS \\
\hline$A \times C$ & NS & NS & NS \\
\hline $\mathrm{S} \times \mathrm{C}$ & NS & NS & NS \\
\hline$A \times S \times C$ & NS & NS & NS \\
\hline
\end{tabular}

Means followed by the same letter (s) in a column are not significantly different at $5 \%$ level of probability using Student-Newman Keuls Test. *=significant at $5 \%$; **= significant at $1 \%$;

$\mathrm{NS}=$ not significant 
Table 4 shows the effect of antitranspirant and moisture stress on marketable fruit yield of tomato in both seasons and combined. Significant difference between the antitranspirants on marketable fruit yield was observed only in 2012 season where application of Salicylic acid had produced plants with the highest marketable fruit yield $\left(8.80 \mathrm{t} \mathrm{ha}^{-1}\right)$ while application of Benzoic acid had plants with the lowest marketable fruit yield $\left(7.31 \mathrm{t} \mathrm{ha}^{-1}\right)$. Stress had significant effect on marketable fruit yield only in 2012 season where stress imposed at flowering stage produced plants with the highest marketable fruit yield (9.54) while stress imposed at vegetative stage produced plants with the lowest marketable fruit yield (7.51) although statistically at par with plants stressed at fruit setting stage (7.11). Concentration effect on marketable fruit yield was significant in both seasons and combined where application of 400 ppm of antitranspirant produced plants with the highest marketable fruit yield $(9.61,5.70$ and $7.65 \mathrm{t} \mathrm{ha}^{-1}$ ) while the lowest marketable fruit yield was recorded with the application of $0 \mathrm{ppm}$ of antitranspirant $\left(5.95,3.76\right.$ and $\left.4.85 \mathrm{t} \mathrm{ha}^{-1}\right)$. Interaction effect on marketable yield was significant only in 2012 and combined seasons (Table 4).

Table 4: Effect of Antitranspirants and Moisture Stress on Marketable Fruits Yield ( $\mathrm{t} \mathrm{ha}^{-1}$ ) of Tomato at Kadawa in 2012, 2013 Dry Seasons and Combined

\begin{tabular}{|c|c|c|c|}
\hline \multirow[t]{2}{*}{ Treatments } & \multicolumn{3}{|c|}{ KADAWA } \\
\hline & 2012 & 2013 & Combined \\
\hline \multicolumn{4}{|l|}{ Antitranspirants (A) } \\
\hline Benzoic acid & $7.31 b$ & 4.83 & 6.07 \\
\hline Salicylic acid & $8.80 a$ & 4.72 & 6.76 \\
\hline Level of significance & $*$ & NS & NS \\
\hline $\mathrm{SE} \pm$ & 0.424 & 0.620 & 0.773 \\
\hline \multicolumn{4}{|l|}{ Stress (S) } \\
\hline Vegetative & $7.51 b$ & 4.97 & 6.24 \\
\hline Flowering & $9.54 a$ & 4.29 & 6.91 \\
\hline Fruit setting & $7.11 \mathrm{~b}$ & 5.07 & 6.09 \\
\hline Level of significance & $*$ & NS & NS \\
\hline $\mathrm{SE} \pm$ & 0.424 & 0.620 & 0.773 \\
\hline \multicolumn{4}{|l|}{ Concentrations ppm (C) } \\
\hline 0 & $5.95 c$ & $3.76 \mathrm{~b}$ & $4.85 c$ \\
\hline 200 & $8.03 b$ & 4.46ab & $6.24 b$ \\
\hline 400 & $9.61 a$ & $5.70 a$ & $7.65 a$ \\
\hline 600 & $8.63 a b$ & $5.18 a b$ & $6.90 a b$ \\
\hline Level of significance & $*$ & $*$ & $*$ \\
\hline $\begin{array}{l}\mathrm{SE} \pm \\
\text { Interactions (I) }\end{array}$ & 0.417 & 0.468 & 0.631 \\
\hline$A \times S$ & $*$ & NS & NS \\
\hline$A \times C$ & $*$ & NS & NS \\
\hline $\mathrm{S} \times \mathrm{C}$ & * & NS & $*$ \\
\hline$A \times S \times C$ & NS & NS & NS \\
\hline
\end{tabular}

Means followed by the same letter(s) in a column are not significantly different at $5 \%$ level of probability using Student-Newman Keuls Test. *=significant at $5 \%$; ** = significant at $1 \%$; NS= not significant

Results of non-marketable fruit yield of tomato is presented in Table 5. There was no significant difference statistically between the antitranspirant on non- marketable fruit yield of tomato in both seasons. However, stress had significant effect on non- marketable fruit yield only in 2012 season where plants that were stressed at the vegetative stage produced plants with the highest non- marketable fruit yield $\left(2.65 \mathrm{t} \mathrm{ha}^{-1}\right)$ than those plants stressed at fruit setting stage (1.48) and flowering stage (2.08). There was no significant difference statistically between the concentrations on non- marketable fruit yield of tomato. Significant interaction was observed only in 2012 between antitranspirants and stress (Table 5). 
BAJOPAS Volume 14 Number 1,June, 2021

Table 6 shows the effect of antitranspirants and moisture stress on total fruit yield of tomato.

There was significant difference between the antitranspirants on total fruit yield only in 2013 season where application of Benzoic acid produced plants with significantly higher total fruit yield (3.76 $t$ ha $^{-1}$ ) than those sprayed Salicylic acid $\left(3.06 \mathrm{t} \mathrm{ha}^{-1}\right.$ ) while non-significant effect was observed stress stages on total fruit yield in both seasons and combined. Concentration had significant effect on tomato total fruit yield only in 2012 season and combined. In 2012 season, application of 400 ppm of antitranspirant recorded plants with the highest (3.98 tha-1) total fruit yield even though statistically at par with 200 and 600 ppm while control had the lowest total fruit yield $\left(2.62 \mathrm{t} \mathrm{ha}^{-}\right.$ ${ }^{1}$ ).Similar trend was observed in 2012 and 2013 seasons combined. Interaction between antitranspirant and stress, antitranspirant and concentration as well as among antitranspirant, stress and concentration on total fruit yield of tomato was significant only in 2012 season (Table 6).

Table 7 shows the interaction between the two and three factors under consideration on total fruit yield of tomato at Kadawa in 2012 season.
Looking at the antitranspirants under different concentrations, application of $400 \mathrm{ppm}$ of Salicylic acid had plants with significantly higher total fruit yield $\left(4.27 \mathrm{t} \mathrm{ha}{ }^{-1}\right)$. When the concentrations were considered, the control had significantly lower total fruit yield $\left(2.59 \mathrm{t} \mathrm{ha}^{-1}\right)$ even though statistically at par with the other concentrations. Looking at the concentrations under antitranspirant and stress stage, there was significant difference statistically except when 400ppm of Salicylic acid was applied at fruiting stage that had plants with a significantly higher total fruit yield $\left(6.66 \mathrm{t} \mathrm{ha}^{-1}\right)$. Under all concentrations, application of 600 ppm Benzoic acid at fruiting stage had plants with significantly lower total fruit yield $\left(1.47 \mathrm{t} \mathrm{ha}^{-1}\right)$ than all the other concentrations even though at par with $400 \mathrm{ppm}$. Looking at the antitranspirant under different stress stages, application of Salicylic acid at fruiting stage had plants with significantly higher total fruit yield $\left(4.51 \mathrm{t} \mathrm{ha}^{-1}\right)$ than the other stages although at par with Benzoic acid at flowering stage $\left(4.50 \mathrm{t} \mathrm{ha}^{-1}\right)$. When the stress stages were considered, stressing the plant at fruiting stage had plants with significantly lower total fruit yield $\left(2.08 \mathrm{t} \mathrm{ha}^{-1}\right)$ (Table 7).

Table 5: Effect of Antitranspirants and Moisture Stress on Non-Marketable Fruits Yield ( $\mathrm{ha}^{-1}$ ) of Tomato at Kadawa in 2012, 2013 Dry Seasons and Combined.

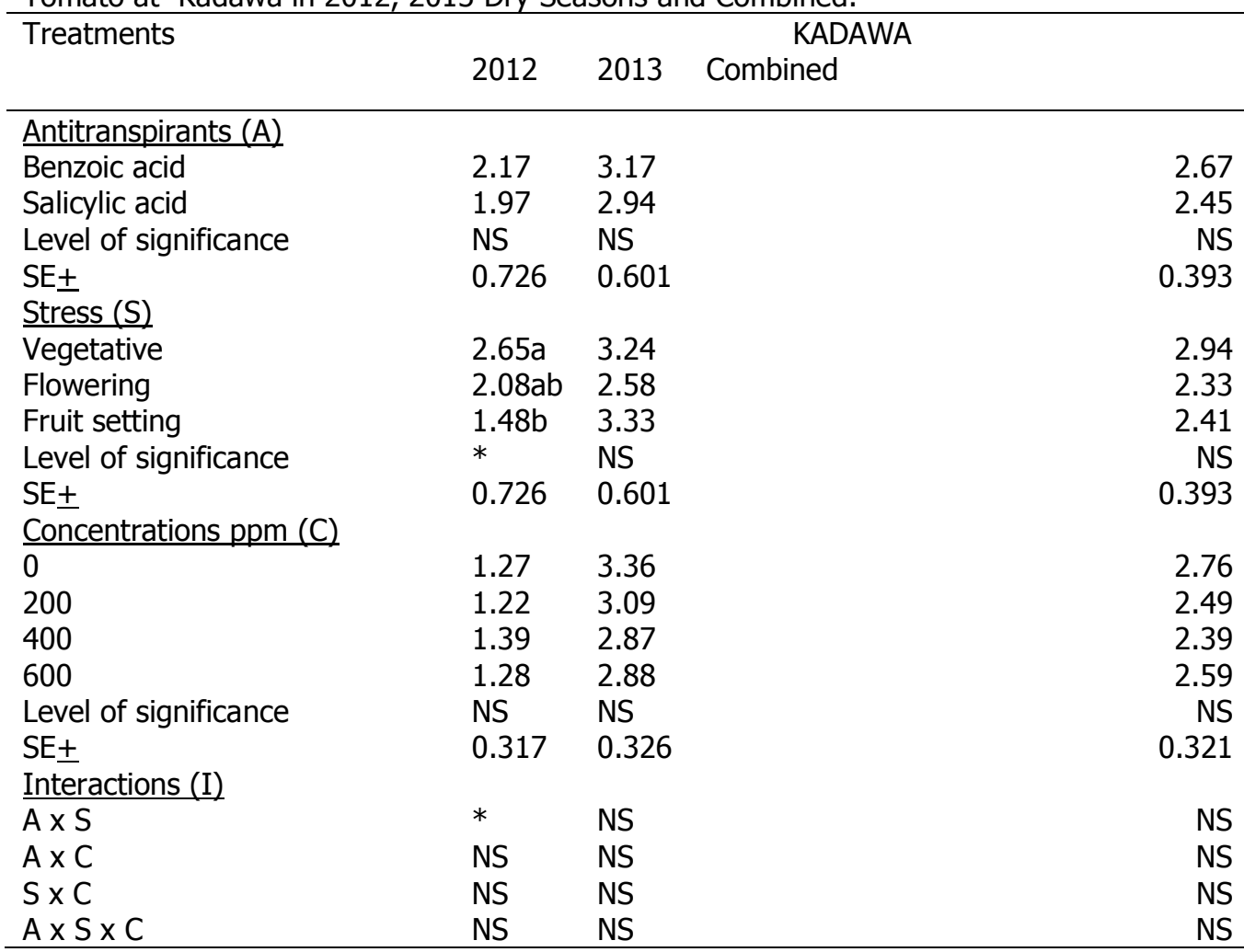

Means followed by the same letter(s) in a column are not significantly different at $5 \%$ level of probability using Student-Newman Keuls Test. *=significant at $5 \%$; **= significant at $1 \%$; NS= not significant 
BAJOPAS Volume 14 Number 1,June, 2021

Table 6: Effect of Antitranspirants and Moisture Stress on Total Fruit Yield ( $t \mathrm{ha}^{-1}$ ) of Tomato at Kadawa in 2012, 2013 Dry Seasons and Combined.

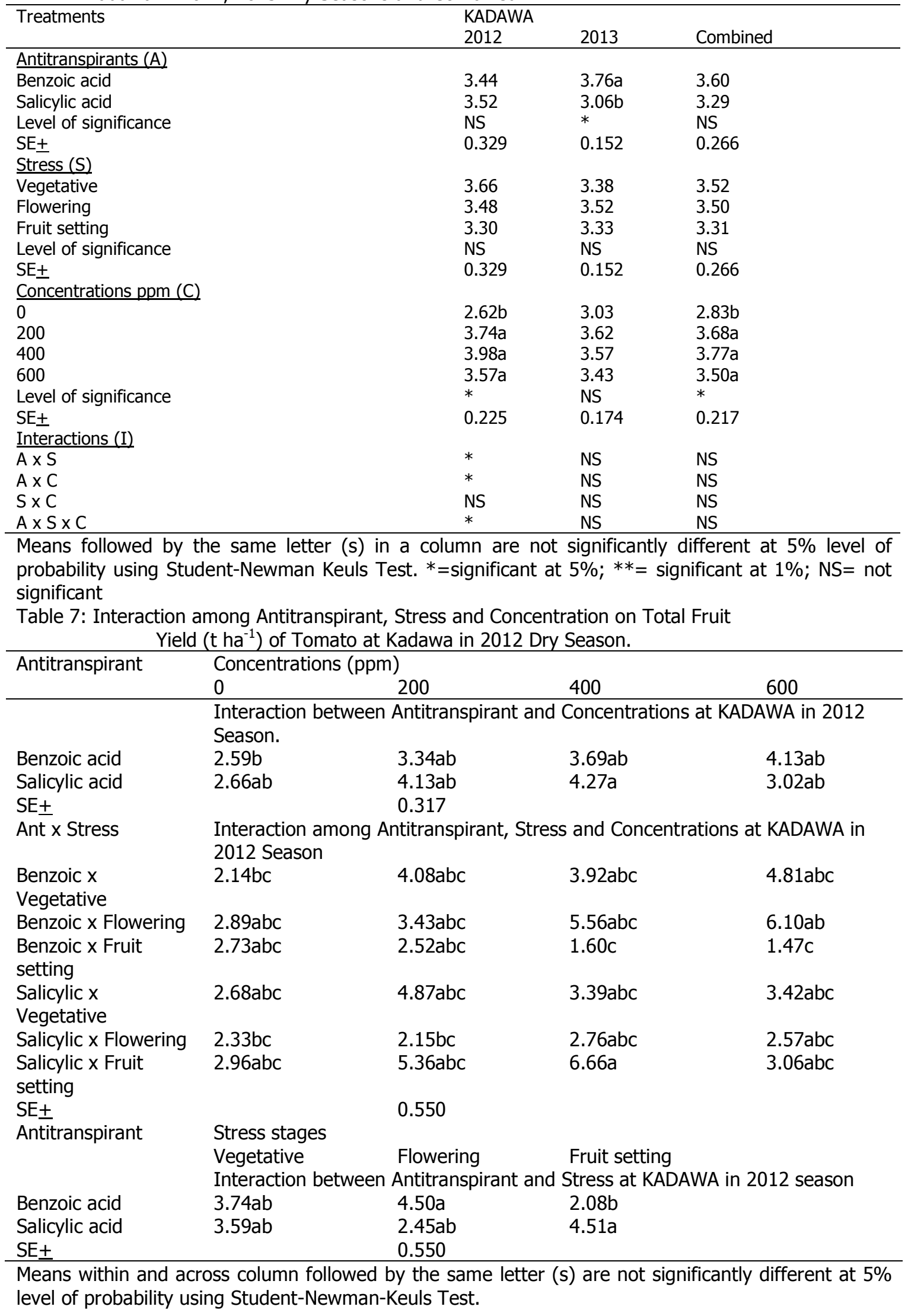


BAJOPAS Volume 14 Number 1,June, 2021 DISCUSSION

The non- significant difference between the antitranspirants in both seasons on number of fruits plant $^{-1}$ of tomato indicated that the antitranspirants had no effect on number of fruits plant ${ }^{-1}$. This result is in contrast with the findings of MacDonald et al., (2010) who reported that pre-conditioning of tomato with $10 \mathrm{mg} \mathrm{L}^{-1} \mathrm{Amboil}$ increase number of fruit plant ${ }^{-1}$ by $65.1 \%$. The difference observed between the antitranspirants on marketable yield of tomato where Salicylic acid had higher marketable fruit yield than Benzoic acid could be attributed to the higher values of leaf area, crop growth rate and total dry matter obtained from plants that were sprayed with Salicylic acid. Higher performance of Salicylic acid than Benzoic acid could also be attributed to the differences in the formulation of the antitranspirants. This is due to the fact that Salicylic acid is in form of powder while Benzoic acid is in granular form. This could result in faster dissolution of Salicylic acid and its subsequent penetration and retention on the leaves. This result is in contrast with the findings of Del Amor and Rubio (2009) who reported that total marketable fruit yield was not affected by antitranspirants. Application of Salicylic acid resulted in higher average fruit weight of tomato than Benzoic acid. This could be attributed to the effect of the Salicylic acid on marketable yield which follows similar trend. Application of Benzoic acid had produced plants with the highest weight of non-marketable yield while application of Salicylic acid recorded the lowest weight of non-marketable fruit yield. This could be due to the higher number of fruits per plant and average fruit weight recorded by application of Salicylic acid. This result is in harmony with that of Kirda et al., (2004).Benzoic acid had higher total fruit yield than Salicylic acid. This could be attributed to the higher non-marketable yield which could have added more weight to the total yield. Martinez et al., (2001) found that application of antitranspirant increased fruit yield. MacDonald et al. (2010) also reported that preconditioning with $10 \mathrm{mg} \mathrm{L}^{-1}$ Amboil significantly resulted in an increase of $44 \%$ in tomato weight. However, this finding contradicted that of Irmak et al., (1999) who reported noneffects of the antitranspirant on total fruit yield. Tomato crop stressed at the fruiting stage resulted in higher number of fruits plant ${ }^{-1}$ than when the crop was stressed at the vegetative and flowering stages. This could probably be attributed to the higher number of branches and leaf area recorded by the crop at this stage. High leaf area means higher photosynthetic rate which enhanced both growth and yield characters of the crop as reported by (Sharp, 1996). This result supported the findings of Nuruddinet al., (2003) who reported that plants stressed only during the flowering stage showed fewer but bigger fruits. Stress imposed at the fruiting stage had plants with higher marketable fruit yield than tomato stressed at vegetative and flowering stages. This could be attributed to the effect of the treatment on total number of fruits plant ${ }^{-1}$. Result is in contrasts with the findings of Nuruddin et al., (2003) who reported that the marketable yield were significantly lower on tomato stressed at flowering stage. Tomato stressed at the vegetative stage had heavier fruit weight than when stress was imposed at fruit setting and flowering stages. This is possible due to the fact that the crop might have recovered from stress imposed before the critical period of water requirement at reproductive stage. This supported Nuruddin et al., (2003) who reported that fresh fruit weight was greatest from tomato stressed at vegetative than when stress was imposed at flowering and fruit setting stages. Stressed imposed at the vegetative stage had higher total fruit yield than those stressed at the flowering and fruit setting stages. This indicated that the reproductive stage is the critical stage of water requirement in tomato. May and Gonzales (1999) reported that $60 \%$ depletion of available moisture significantly reduced yields by $15 \mathrm{Kg} \mathrm{ha}^{-1}, 40 \%$ depletion reduced yields by $4 \mathrm{Kg} \mathrm{ha}^{-1}$ less than the $20 \%$ depletion treatment. They also reported that 20 to 60 days water stress before harvest during fruit development and ripening (late stress) resulted in similar reduction in yield. Tomato that received $400 \mathrm{ppm}$ of the antitranspirant had higher number of fruits plant ${ }^{1}$ than the other concentrations. This could be due to the fact that higher rates of antitranspirant usually results in phytotoxicity which reduces growth and yield of the crop as reported by El-Kobbia and Ibrahim, (1986). This suggest that this rate of antitranspirant might have encouraged more moisture conservation and its use in production of more assimilate and its subsequent translocation to the fruit. MacDonald et al. (2010) reported that preconditioning with $10 \mathrm{mg} \mathrm{L}^{-1} \mathrm{Amboil}$ resulted in an increase of $65.1 \%$ in number of tomatoes fruit plant ${ }^{-1}$. However, application of $200 \mathrm{ppm}$ of antitranspirant produced plants with heavier fruit weight than the other concentrations indicating that the character responds positively to application of the antitranspirant. Del Amoret al., (2006) had reported that the use of vapour guard at $1 \%$ increased fruit weight by $9.5 \%$. Application of $200 \mathrm{ppm}$ of the antitranspirant recorded plants with larger diameter than the 
BAJOPAS Volume 14 Number 1,June, 2021

other levels. This could be attributed to the effect of the treatment on fruit weight which followed similar trend. High phytotoxicity was associated with higher concentrations of antitranspirant as reported by El Kobbia and Ibrahim (1986). Application of $200 \mathrm{ppm}$ of antitranspirant produced plants with higher total fruit yield than when no antitranspirant was applied. This could be associated with the effect of this treatment on characters like fruit weight and fruit diameter which are all positively correlated with fruit yield. MacDonald et al., (2010) reported that preconditioning with $10 \mathrm{mg}$ $\mathrm{L}^{-1}$ Amboil resulted in an increase of $65.1 \%$ in number of tomatoes on each plant and $44 \%$ in tomato mass (weight) which resulted to an increase of fruit yield by $143 \%$. Application of $600 \mathrm{ppm}$ of antitranspirant recorded the highest fruit dry matter than the control. It can be assumed that low Salicylic acid concentrations inhibit ethylene biosynthesis (Huang et al., 1993; Srivastava and Dwivedi, 2000) while a high concentration stimulates it. However application of Benzoic acid at $400 \mathrm{ppm}$ had higher weights of marketable yield than application of Salicylic acid. This could be related to higher performance of Salicylic acid on nonmarketable yield. The implication here is that for farmers that sell their fruit fresh, Benzoic acid could be the best option to them because application of Benzoic acid recorded plants with highest number and weight of non-marketable yield. But for farmers that processed tomato into canned product, Salicylic may be desirable. Application of $200 \mathrm{ppm}$ of Salicylic acid was observed to have higher total fruit yield than Benzoic acid. This could be related to higher number of branches and fruits plant $^{-1}$ which translate into higher total fruit.

Larger fruit diameter was obtained from plants stressed at the vegetative stage with application of $200 \mathrm{ppm}$ of antitranspirant. This might be due to the fact that tomato plants stressed at vegetative stage usually recover from stress before the reproductive phase. Plants stressed at fruiting stage and $400 \mathrm{ppm}$ concentration of antitranspirant applied recorded higher number of fruits plant ${ }^{-1}$. This could be attributed to the

\section{REFERENCES}

Amans, E. B.; Erinle, I. D. and Bodunde, J. G. (1986). The potentials of some tomato cultivars for hot season production in Northern Nigeria. Paper presented at the $8^{\text {th }}$ Annual Conference of Horticultural Society of Nigeria.

Csizinszky, A. A. (1996). Micro irrigation and Antitranspirant rates and cultivar effect effects of antitranspirant at this rate and stressed stage on plant height, number of branches and dry matter which followed similar trend (Topcuet al., 2007). Fruits with higher weights were obtained from plants stressed at vegetative stage with application of $600 \mathrm{ppm}$ of antitranspirant. It implies that application of this rate of antitranspirantat this stage produce bigger fruit and this resulted to higher marketable yield. This could be attributed to the effects of this rate of antitranspirant at this stress stage on other yield components like fruit diameter, number of fruits plant ${ }^{-1}$ and average fruit weight which followed similar trend. Higher fruit dry matter was obtained when 600 ppm concentration of antitranspirant was applied to plants stressed at the flowering stage. This might be due to the higher weights of marketable yield obtained from plants stressed at the flowering stage when $600 \mathrm{ppm}$ of antitranspirant was applied (Nuruddin et al., 2003). Higher fruits yield was obtained when $400 \mathrm{ppm}$ concentration of Salicylic acid was applied at the fruiting stage. This could be attributed to higher yield parameter recorded such as fruit diameter, number of fruits plant ${ }^{-1}$, average fruit weight and weight of marketable yield which are important yield determinants. This result is in harmony with the findings of (Csizinszky, 1996) who reported that yields of tomato and bell pepper were affected by the interaction of the three experimental factors where yields of improved cultivar with high irrigation rate and with 10 Antitranspirant application was higher than yield with the same high irrigation rate and with water control.

\section{CONCLUSION}

Salicylic acid demonstrated higher performance than benzoic acid in most of the yield attributes of tomato, however, benzoic acid had higher marketable yield. Flowering and fruiting growth stages were found to be the critical growth stages for moisture stress of tomato. Applying $400 \mathrm{ppm}$ of salicylic acid at fruit setting produced the highest total fruit yield (6.66 tha$\left.{ }^{1}\right)$.

on Tomato and Bell pepper Yields. Prov. Fla. State. Hort. Soc. 109: 141-145.

Harlan, J.R. (1984). Agriculture Origins: Centers and Non-Centers. Science 174:468-473.

Harvey, M., Quilley, S. and Beynon, H. (2002). Exploring the Tomato. Transformations of Nature, Society and Economy. Edgar Publishing, Cheltenham, UK, 304 pp.

Huang, Y. F, Chen, C. T. and Kao, C. H. (1993). Salicylic acid inhibits the biosynthesis 
BAJOPAS Volume 14 Number 1,June, 2021

ofethylene in detached rice leaves. Plant Growth Regulators 12: 79-82.

Inmaculada, N., Veronica, G., Javier, G. and Jesus Periog, M. (2011). Chemical profile, functional and antioxidant properties of Tomato peel fibre. Food Research International (44) 1528-1538 Journal home page: www. Elsevier.com/locate/foodes.

Irmak, A., Jones, J. W., Stanley, C. D., Hansen, J. W., Irmak, S. and Boote, K. J. (1999).Some effects of antitranspirant (VapourGard) on tomato growth and yield.Soil and crop Science Society of Florida proceedings. P. 118-122.

Kirda, C., Cetin, M., Dasgan, Y., Topcu, S., Kaman, H., Ekici, B., Derici, M. R. and Ozguven, A. I. (2004). Yield response of greenhouse grown tomato to partial root drying and conventional deficit irrigation. Agricultural Water Management 69:191201.

MacDonald, M. T., Lada, R. R., Robinson, A. R. and Hoyle, J. (2010). The benefits of Amboil in promoting germination, growth and drought tolerance can be passed on to next generation of Tomato seedlings. Journal of plant growth regulators 29: 357-365.
Martinez, P. F., Tartoura, S. A. and Roca, D. (2001). Air humidity, transpiration and bloosom-end-rot in soilless sweet pepper culture. Acta Horticultural 559: 425- 429.

May, D. M. and Gonzales, J. (1999). Major California processing tomato cultivars respond differently in yield and fruit quality to various levels of moisture stress. Acta Horticulturae 487: 525-529.

Nuruddin, M M. and Madramootoo, C. A., Dodds, G. T. (2003). Effects of Water Stress at Different Growth Stages on Greenhouse Tomato Yield and Quality. Hort Science 7: 1389-1393.

Sharp, R. E. (1996).Regulation of plant growth responses to low soil water potential. Horticultural Science 31(1):36-38.

Srivastava, M. K. and Dwivedi, U. N. (2000). Delayed ripening of banana fruit by Salicylic acid. Plant Science, 158: 87-96.

Topcu, S., Kirda, C., Dasgan, Y., Kaman, H., Cetin, M., Yazici, A., and Bacon, M. A. (2007).Yield response and $\mathrm{N}$ - fertiliser recovery of tomato grown under deficit irrigation. European Journal of Agronomy 26: 64-70. 